\author{
Available online at Dakwah: Jurnal Kajian Dakwah dan Kemasyarakatan \\ http://journal.uinjkt.ac.id/index.php/dakwah \\ Dakwah: Jurnal Kajian Dakwah dan Kemasyarakatan, 23 (2), 2019, 85-99
}

\title{
Islam, Multikulturalisme, dan Pancasila
}

\author{
Sahirul Alim \\ Universitas Islam Negeri Syarif Hidayatullah Jakarta \\ syahirulalm@uinjkt.ac.id
}

\begin{abstract}
Islam is not only a theological system; it has formed a holistic civilization, along with the history of humanity since more than 15 centuries ago. The doctrinal principles of Islam almost never conflict with cultural realities, except when these sacred teachings really hate anything which is contrary to human values. Islam recognizes the principle of multiculturalism as it is confirmed in the Qur'an. That is why, the process of islamization in Indonesia spread quickly and almost doctrinal matters of Islam were in accordance with the values of Indonesian tradition and culture. Indonesia is the largest Muslim country in the world, with a diversity of cultures, languages and religions (multiculturalism) but is able to maintain unity in the diversity of its society by adhering a state philosophy and ideology namely Pancasila. A unique experience of an "organic-multiculturalism" almost went unnoticed, that Pancasila was a synthesis of Islamic social values within multicultural circumstances integrating any diversities into the form of the "Negara Kesatuan Republik Indonesia" (NKRI).
\end{abstract}

Keywords: Islam, multiculturalism, Pancasila, Indonesia

\begin{abstract}
Abstrak
Islam bukan hanya sistem teologis; Ia telah membentuk peradaban holistik, seiring dengan sejarah umat manusia sejak lebih dari 15 abad yang lalu. Prinsip doktrinal Islam hampir tidak pernah bertentangan dengan realitas budaya, kecuali jika ajaran sakral ini sangat membenci segala sesuatu yang bertentangan dengan nilai kemanusiaan. Islam mengakui prinsip multikulturalisme seperti yang ditegaskan dalam Al-Qur'an. Oleh karena itu, proses islamisasi di Indonesia menyebar dengan cepat dan hampir semua masalah doktrinal Islam sesuai dengan nilai-nilai tradisi dan budaya Indonesia. Indonesia merupakan negara muslim terbesar di dunia, dengan keragaman budaya, bahasa dan agama (multikulturalisme) namun mampu menjaga persatuan dalam keberagaman masyarakatnya dengan menganut falsafah dan ideologi negara yaitu Pancasila. Pengalaman unik dari "multikulturalisme organik" hampir luput dari perhatian, bahwa Pancasila merupakan sintesis nilai-nilai sosial Islam dalam lingkungan multikultural yang mengintegrasikan keragaman ke dalam bentuk "Negara Kesatuan Republik Indonesia” (NKRI).

Kata kunci: Islam,multikuluralisme, Pancasila, Indonesia
\end{abstract}

Permalink/DOI: http://doi.org/10.15408/dakwahv23i2.13938 


\section{Pendahuluan}

Sebagai sistem sosial, Islam telah secara definitif membentuk suatu peradaban yang ditopang oleh beragam tradisi dan nilai-nilai sosio-kultural yang terintegrasi ke dalam suatu komunitas religius yang dikenal dengan istilah "ummah". Nilai-nilai doktrinal yang diyakini bersumber dari Wahyu tetap tidak berubah dan berada dalam wilayah sakral sebagai ciri khas sebuah agama. Disisi lain, nilai-nilai tradisi dan budaya yang secara beragam dibawa oleh setiap Muslim kedalam ummah, tidak serta merta di "islamisasi" atau tunduk dibawah subordinasi ketetapan doktrinalnya. Doktrin Islam hampir tak ada yang bertentangan dengan realitas masyarakat multikultur, namun kebanyakan justru "menyesuaikan" atau terkadang melebur ke dalam bangunan struktur ummah yang ada, tidak mendominasi tetapi hidup berdampingan dengan berbagai nilai-nilai budaya masyarakat lokal.

Kenyataannya, apa yang sejauh ini dipersepsikan orang tentang peradaban Islam, tentu saja merupakan bangunan multikultur, hasil dialektika cukup panjang antara "yang normatif" dan "yang historis". Itulah sebabnya, Islam-yang pengalamannya berbeda dari tradisi agama-agama lain-memiliki kemampuan secara normatif untuk diterima dalam realitas sosial manapun, karena ajaran-ajarannya terutama berwatak egaliter dan humanistik. Masyarakat Indonesia, misalnya, hampir tanpa kesulitan dan hampir tanpa konflik sejak awalnya menerima proses islamisasi yang dibawa oleh para saudagar dari berbagai latar belakang etnik: Arab, India, Persia, atau Cina, bahkan dalam kurun waktu yang tidak terlampau lama, Islam dipastikan masuk dan menguasai batin masyarakat Indonesia.

Fleksibilitas ajaran Islam-dilihat dari aspek doktrinalnya yang menekankan "kemudahan" dan moderasi memungkinkan agama ini hidup berdampingan dalam suatu entitas masyarakat yang multikultur, seperti di Indonesia. Kemampuan masyarakatnya yang sedemikian mengagumkan dalam hal penerimaan nilai-nilai baru yang berasal dari luar komunitasnya, merupakan pengalaman multikultural yang sulit dicari tandingannya. Islam Indonesia, tentu saja terbentuk dalam suasana multikultur yang hampir tanpa pertentangan sedikitpun. Perbedaan bahasa, tradisi, budaya, nilainilai komunal, bahkan agama dan keyakinan, menyatu dalam sebuah kehidupan religius yang khas dan terlampau sulit dipisahkan. Entitas multikultur ini dalam masyarakat Indonesia kemudian diabadikan kedalam suatu konsensus politik bernama "Pancasila", sebuah pengakuan identitas multikulturalisme dalam konteks berbangsa dan bernegara.

\section{Islam Sebagai Suatu Peradaban Multikultural}

Dalam banyak hal, Islam tentu saja mengakui prinsip multikultural, ketika prinsip tersebut didefinisikan sebagai "penerimaan atas perbedaan ras, bahasa, agama, dan budaya dalam suatu komunitas sosial” (Wordpower, 2011). Hal ini dapat dibuktikan melalui pengertian "islam" yang dalam perubahan semantiknya, "istislam" mengandung konotasi "kepasrahan" atau "ketundukan" tanpa perlawanan (inqâd bi dûni al-muqâwamah) DAKWAH, Vol. 23, No. 2, 2019 
(www.almaany.com). Sikap pasrah dan tunduk ketika hadir dalam konteks sosial, cenderung mudah menerima setiap perbedaan, terlebih bahwa Islam secara definitif, mempunyai pengalaman yang cukup baik dalam mengintegrasikan nilai-nilai doktrinal ke dalam sistem komunal. Informasi ini dapat ditelusuri, ketika Islam mengakui bahwa seluruh nabi dan rasul adalah "muslim" sekalipun diutus kepada komunitas berbeda-beda. Realitas multikultural juga dipertegas melalui pernyataan Alquran: "Dan di antara tanda- tanda kekuasaan-Nya ialah menciptakan langit dan bumi dan berlainlainan bahasamu dan warna kulitmu” (QS. 30:22).

Konsep ummah yang diproyeksikan Nabi di Madinah sebag Bahasa merupakan produk sosial yang dibentuk melalui jaringan multikultur yang rumit, sehingga apa yang disebut bahasa merupakan hasil konvensi sosial yang disepakati dan kemudian dilestarikan bersama-sama secara turun temurun. Karena bahasa itu hasil konvensi, maka setiap masyarakat atau bangsa memiliki bahasa tersendiri dan bahkan bisa menciptakan bahasa baru (Hidayat, 2004). Perbedaan bahasa dan ras-sebagaimana Alquran menyebutnya "alwan" yang berkonotasi "bermacammacam jenis"-juga merupakan unsur-unsur budaya yang harus diterima sebagai kenyataan multikultural. Islam, sebagai agama dan sistem keagamaan, jelas mengakui prinsip keragaman budaya tersebut.

Islam tidak cukup didefinisikan secara teologis, tetapi harus juga dilihat sebagai suatu realitas historis, di mana ia merupakan sistem peradaban yang lengkap. G.E. von Grunebaum mendefinisikan Islam sebagai suatu budaya dan peradaban, sehingga dapat dipahami ketika studinya tentang Islam lebih berorientasi antropologi budaya dan sejarah. Disisi lain, W.C Smith memandang Islam sebagai sebuah agama, sehingga mendorong dirinya memahami Islam melalui model hubungan antara agama komunal atau personal dan tradisi keagamaan tertentu (Waardenburg, 1993). Menghubungkan Islam dan

multikulturalisme dalam konteks historissosiologis, akan tampak suatu cakrawala sosial-budaya yang integratif, unifikasi dalam diversitas tradisi, budaya, maupun kelompok, dimana sikap individual terikat oleh suasana iman komunal, sekalipun masing-masing individunya tidak saling mengenal.

Multikulturalisme dalam tradisi Barat, seringkali didefinisikan sebagai suatu strategi dalam integrasi sosial kedalam satu milieu kebudayaan mainstream tertentu melalui penyatuan berbagai kelompok etnis yang ada sebagai representasi multikultur yang disepakati, baik norma, nilai, dan sebagainya yang dilebur mengikuti suatu kebudayaan dominan secara organik atau dibentuk oleh lembaga tertentu secara mekanik (Nagy, 2013). Konsep ini dalam berbagai aplikasinya justru mengalami kegagalan-sebagaimana Kymlica-sebab multikulturalisme, pada akhirnya sekadar bentuk lain dari perluasan semangat liberalisme yang berlebihan dalam mengangkat hak-hak kelompok minoritas, seperti hak perempuan, homoseksual, dan kelompok minoritas etnis lainnya, yang dalam beberapa kasus, justru berasal dari kelompok imigran. Padahal, 
multikulturalisme seharusnya memberikan jaminan hak-hak kultural, kepada seluruh kelompok etnis, ras, dan agama dengan melindungi seluruh hak warga negaranya, tanpa kecuali (Nagy, 2013).

Pada tahap tertentu, multikulturalisme seringkali meminggirkan aspek budaya lokal, bahkan budaya asli suatu masyarakat justru menjadi terasing sehingga mereka tidak mengenal lagi budayanya sendiri. Liberalisme yang menjadi akar dari multikulturalisme justru gagal dalam membaca realitas masyarakat yang berbudaya, tenggelam dalam fanatisme kekelompokkan dan etnis tertentu yang justru menciptakan suasana diskriminarif yang semakin meluas. Parekh menyarankan agar tema multikulturalisme diganti dengan konsep "identitas nasional" dalam suatu kerangka institusional-politik, sehingga setiap warga negara dapat berpartisipasi secara langsung dalam konteks kepolitikan dengan hak-hak yang sama dan sejajar (Nagy, 2013).

Istilah "multikulturalisme" sendiri dalam perkembangannya memang lebih dekat kepada aspek politik, sebab pada akhirnya terdapat upaya mengintegrasikan berbagai perbedaan yang hidup dalam suatu realitas sosial yang dilakukan atas dasar kesamaan politik. Dalam tradisi Islam, integrasi sosial terjadi secara organik, melalui peleburan berbagai bentuk kesukuan-dengan menghilangkan kultur dominan-etnik dan agama dalam suatu identitas baru bernama "ummah". Lebih jauh, Goldziher menyebut bahwa Nabi Muhammad telah memancangkan gagasan penggabungan suatu komunitas etis dan religius yang tunggal (Goldziher, 1991) sehingga tampak disini suatu upaya mempersatukan berbagai macam agama, suku, tradisi, dalam suatu komunitasbangsa yang integratif.

Istilah "ummah" atau umat kemudian menjadi populer dalam tradisi Islam bahkan menjadi ciri khas sepanjang sejarahnya, sebagai sebuah frasa yang menunjuk pada suatu komunitas religius (Hodgson, 1999) atau "bangsa" dengan ikatan-ikatan kultural berdasarkan keimanan tidak lagi berdasarkan formasiformasi kekeluargaan, kesukuan, atau identitas primordial lainnya. Umat, menempati ruang multikultural dalam bentangan kehidupan kolektif, baik secara sosial dan politik. Maka, setelah proses penetrasi Islam ke berbagai belahan dunia, istilah "umat Islam" identik dengan pengertian multikultural, sekalipun terdapat tingkat asosiasi kultur yang berbeda-beda di setiap wilayahnya. Masyarakat Muslim dengan kultur Arab yang homogen pasti tidak akan sama tingkat asosiasi dan integrasi sosialnya dengan masyarakat Muslim di Indonesia yang heterogen.

Pemaknaan umat yang pada awalnya memiliki konotasi beragam-karena kadang menunjuk pada etnis tertentu, kelompok agama, atau moralitas-yang

keseluruhannya menunjukkan aspek multikulturalisme-justru seolah berhenti pada aspek masyarakat politik atau komunitas dimana terdapat suatu kekuasaan yang berdaulat. Umat, menjadi suatu komunitas Islam tunggal yang universal yang mencakup seluruh wilayah dimana kekuasaan kaum Muslim berhasil dimantapkan dan dimana hukum Islam diberlakukan (Lewis, 1994). Cukup dipahami ketika belakangan muncul klaim yang berasal dari berbagai penulis Muslim, 
bahwa yang dimaksud oleh Alquran sebagai "umat terbaik" (khairu ummah) yang "ideal" (ummatan wasatha) adalah komunitas Islam, sebab ia mampu mengintegrasikan suatu kenyataan religius dan etnis sekaligus, yang sakral maupun temporal secara bersamaan.

Berbagai acuan perihal umat ini yang dibaca dalam konteks masyarakat Madinah dengan berbagai perluasannya membawa ke arah suatu kesimpulan dimana Islam tidak sekadar sebuah agama, namun merupakan suatu persekutuan politik. Hal ini dibenarkan oleh W Montgomery Watt, seraya menunjukkan suatu keunikan dimana agama dan perkumpulan politik melebur dalam realitas umat. Menurutnya, umat bukanlah suku atau perserikatan suku-suku, bukan pula suatu kerajaan, tetapi suatu entitas politik yang mempersatukan berbagai perbedaan- perbedaan kelompok sosial kedalam kesatuan politik yang mereka kenal sebagai "ummah". Sampai pada tahap tertentu, Watt meyakini bahwa perkembangan umat Islam belakangan hampir berhenti menjadi sekadar suatu persekutuan politik (Watt, 1982).

Konsep ummah yang diproyeksikan Nabi di Madinah sebagai suatu komunitas Muslim integralistik, justru dibaca secara berbeda oleh beberapa kalangan orientalis, yang menganggap bahwa konsep ummah justru merupakan bagian dari proyek "Arabisasi" atau "nasionalisasi" Islam yang secara disintegratif mengacu pada sejarah "perpindahan arah kiblat" umat muslim dari Masjid al-Aqsha di Yerusalem ke arah Ka'bah di Mekah. Fazlur Rahman menolak asumsi kebanyakan orientalis yang mengambil begitu saja bangunan teori klasik permanen yang berasal dari karya
Snouck Hurgronje, Geschichte de Qorans of Noldeke-Schwally. Teori tersebut telah dielaborasi sedemikian, sehingga mendistorsi kedudukan Nabi secara mendasar dalam konteks misi awal Nabi ketika memperkenalkan ajaran-ajaran Islam. Rahman mendasarkan teorinya atas kenyataan garis genealogi ajaran monoteisme yang membentang "lurus" (hanif) dari Ibrahim hingga Isa (Rahman, 2017), sehingga apa yang dimaksud umat tentu saja bagian dan terpisahkan dari tradisi-tradisi masa lalu yang disempurnakan oleh risalah Nabi Muhammad.

Rahman mengkritisi fakta-fakta yang diajukan dalam teori Noldeke-Schwally yang mengalami distorsi hingga kekeliruan, sebab tidak didukung fakta-fakta material yang lebih fokus sebagai suatu hasil kerja ilmiah. Menurutnya, perubahan arah kiblat yang dijalankan Nabi pada periode Madinah tidak merepresentasikan pergeseran orientasi keagamaan Sang Nabi atau proyek nasionalisasinya! Sebagaimana yang selama ini dipahami oleh kebanyakan sarjana Barat (Rahman, 2017). Nabi, tentu saja berada dalam dua rangkaian peristiwa historis yang tak terpisahkan-Mekah dan Madinahsehingga perkenalannya dengan umat agama lain telah terjalin cukup lama, termasuk ketika komunitas Muslim awal lahir dari Madinah. Sejarawan Ibnu Ishaq pernah mengungkapkan, bahwa beberapa kali terjadi perdebatan teologis antara Nabi dan beberapa orang penganut agama-agama sebelumnya. Hasilnya menunjukkan, dimana perbedaan-perbedaan teologis tidak hanya bertentangan langsung dengan Islam yang pada saat itu diwakili oleh Nabi, tetapi juga perbedaan-perbedaan tersebut, secara 
esensial justru terjadi dalam kalangan internal mereka sendiri (Rahman, 2017).

Fakta ini menunjukkan, bahwa Islam sejak awal memiliki ciri "multikultural" dimana tetap mengakui eksistensi keagamaan masa lalu yang dibawa oleh para nabi sebelum Nabi Muhammad-yang dalam konteks ini dikaitkan dengan agama Yahudi dan Nasrani-dan pada saat bersamaan, doktrin Islam juga mengakui suhuf-suhuf yang dibawa para nabi sebelumnya yang kemudian menjadi kitab suci umat-umat terdahulu. Jika Islam saja menuntut pengakuan atas nabi dan kitab-kitab terdahulu sebagai bagian dari keyakinan doktrinal bagi umatnya, maka wajar jika Nabi Muhammad mengajak kepada umat Yahudi dan Nasrani untuk mengakui Alquran sebagai wahyu yang disampaikan melalui risalah keabiannya, sama halnya ketika Nabi mengakui wahyu yang diturunkan kepada nabi-nabi mereka sebelumnya.

Barangkali, warna yang paling kontras dalam soal kenyataan multikultural adalah Indonesia. Hal ini, tidak saja karena proses islamisasi oleh para pedagang Muslim dengan berbagai latar belakang tradisi dan budayanya, lalu diserap dan berhimpun membentuk masyarakat Nusantara. Namun yang lebih penting adalah suatu kenyataan bahwa masyarakat Indonesia telah sejak awal terbentuk oleh suatu integrasi yang unik, dengan beragam suku, tradisi, budaya, nilai dan etika sosial, bahkan bahasa memiliki kemampuan yang sangat mengagumkan ketika membentuk suatu bangsa yang terintegrasi. Dengan jumlah penduduk beragama Islam sekitar 87 persen, Indonesia memperlihatkan suatu daya tampung yang luar biasa besar, tetapi mampu mengintegrasikan berbagai suku, tradisi, dan budaya.

Indonesia mempunyai rangkaian sejarah panjang dalam hal asimilasi budaya, termasuk bagaimana ajaran Islam masuk secara bertahap dan perlahan-lahan menguasai setiap batin masyarakatnya. Proses konversi masyarakat Indonesia ke dalam Islam, dengan melibatkan seperangkat perbedaan kultur yang tampak saling bertentangan-terutama ragam kebudayaan yang berasal dari dunia Arab, India, atau Persia-sungguh merupakan suatu upaya yang sedemikian sulit. Keberhasilan para pedagang Muslim yang datang ke Indonesia di masa lalu, menjadi alasan utama, bagaimana untuk pertama kalinya ide-ide Islam diperkenalkan kepada masyarakat lokal melalui komunitas multikultural sehingga membentuk Islam Indonesia yang sangat unik, sebab ia berasal dari "banyak sumber" (multiple origins) tidak dibentuk oleh satu varian tradisi atau kebudayaan yang diambil dari sumber tunggal.

Ada suatu kenyataan historis, dimana proses konversi Islam di Indonesia telah melewati beragam akulturasi etnis dan budaya dalam perjalanannya. Para pedagang asal Yaman, misalnya, karena harus melewati Pantai Malabar, tentu saja terpengaruh sedikit banyak oleh budaya- budaya masyarakat lokalnya ketika mereka harus singgah dan menetap untuk beberapa waktu dalam rangka berbisnis. Ditambah para pedagang asal Cina, umumnya mereka menjalin suatu koneksi dengan para pedagang di Vietnam, kemudian dengan Filipina 
Selatan yang kemudian berakhir di pesisir pulau Jawa. Berbagai koneksi ini, telah menciptakan suatu mesin tersendiri dalam hal penyebaran ide-ide Islam yang cukup variatif di Indonesia yang dibawa para pedagang dengan latar belakang multikultur (Rasmussen, 2010).

Islam dan multikulturalisme, ternyata membentuk suatu komunitas yang harmonis, berjalin berkelindan membangun suatu komunitas religius, sehingga apa yang dinamakan kemudian sebagai wujud peradaban Islam berasal dari latar belakang tradisi masyarakat yang berbeda-beda, namun mampu berintegrasi secara politik ke dalam suatu komunitas multikultur melalui ikatan-ikatan iman yang melampaui batas-batas keagamaan mereka. Pandangan atas Islam dan multikulturalisme, didasarkan atas jaringan relasi antartradisi yang dibedakan oleh antropolog Robert Redfield "tradisi besar" dan "tradisi kecil” dalam sejarah Islam. Tradisi besar dibangun melalui literatur-literatur, kesusastraan, yang membentuk suatu peradaban, sedangkan "tradisi kecil" yang merupakan perwujudan dari suku-suku, desa-desa terpencil, serta kelompok masyarakat perkotaan, berproses dalam organisasi sosial dimana setiap kelompok masyarakat harus berupaya sesuai dengan ajaranajaran Alquran dan Sunah dalam berbagai konteks kehidupan dan lingkungan yang berbeda- beda. (Martin, 1982).

\section{Pancasila Sebagai Sebuah "Multikultura- lisme Organik"}

Istilah "multikulturalisme organik" yang dimaksud adalah untuk menunjukkan bahwa proses integrasi di Indonesia masih terus berlangsung secara alami hingga saat ini. Dalam banyak hal, multikulturalisme memang identik dengan integrasi, baik secara budaya, sosial, atau politik dimana terdapat konsensus yang jelas dalam suatu komunitas atau bangsa untuk mengakui keragaman budaya masyarakatnya (Munoz, 1999). Dalam kaitannya dengan Pancasila, saya cenderung menggunakan istilah “integrasi politik", sebab Pancasila sebagai falsafah dan ideologi negara merupakan hasil kompromi politik yang mengintegrasikan dua hal-mengikuti pendapat Weiner-yaitu, asimiliasi dan persatuan dalam keragaman. Asimilasi adalah dijadikannya kebudayaan suku dominan dalam suatu negara sebagai kebudayaan nasional; dan persatuan dalam keragaman (bhineka tunggal ika) menyiratkan bahwa pembentukan kesetiaan nasional dilakukan dengan tidak menghilangkan kebudayaan kelompok minoritas (Sjamsuddin, 1989).

Hefner bahkan mengakui di mana bentuk multikulturalisme yang lebih representatif justru berasal dari beberapa negara baru di Asia Tenggara, seperti Singapura, Malaysia, dan Indonesia. Proses pembentukan mereka menjadi suatu bangsa benar-benar alami, dimana negara-negara ini mampu mengakomodasi banyak kebudayaan dan kelompok etnik yang berbeda-beda tanpa harus didahului oleh pembentukan budaya secara historis atau dijalankan melalui kerangka yang disepakati secara institusional (Nagy, 2013). Multikulturalisme di ketiga negara ini dibentuk secara alami, tanpa 
harus dinyatakan dalam bentuk "kemauan sosial" (social-will) telah dicap sebagai wujud nyata bagi sebuah komunitas yang prulalistik. Di Indonesia, prinsip-prinsip prulalistik diikat secara ideologis oleh nilai-nilai Pancasila dan proses integrasi sosialnya diartikulasikan melalui semboyan bhineka tunggal ika, sehingga membentuk suatu multikulturalisme organik, tetap merawat kenyataan pluralitas dengan menghormati dan toleransi antarsesama warga negara yang dijamin oleh konstitusi negara.

$$
\text { *** }
$$

Segera setelah Indonesia diakui menjadi sebuah negara berdaulat, para pemimpin nasional berkumpul untuk merumuskan konsep kenegaraan seperti apa yang cocok bagi sebuah bangsa baru dengan entitas kultur, bahasa, ras, dan agama yang begitu beragam. Indonesia adalah representasi Muslim terbesar di dunia, sehingga wajar jika perdebatan soal bentuk negara lebih banyak diinisiasi oleh pergumulan pemikiran Islam dan sekuler. Wacana negara Islam atau minimal bernuansa agama, seringkali menguat dalam forum-forum pembahasan yang menyoal bentuk pemerintahan dan bentuk negara. Bangsa yang baru lahir pada saat itu rentan sekali mengalami disintegrasi, jika perumusan konsep kenegaraan ternyata gagal menerjemahkan realitas multikultural yang selama berabad-abad diakui dan diterima dalam ruang-ruang komunal yang integral.

$\begin{array}{lrr}\text { Babak baru yang kemudian } \\ \text { disepakati bersama dalam } & \text { bentuk } \\ \text { multikulturalisme-organik } & \text { adalah } \\ \text { penerimaan rumusan dasar berbangsa dan }\end{array}$

bernegara yang tertuang dalam lima prinsip yang dinamakan Pancasila. Ide dasar soal ini terutama muncul dari pidato tanpa teks seorang pemimpin pergerakan kemerdekaan, Soekarno, dihadapan Panitia Persiapan Usaha Kemerdekaan yang disebut oleh Kahin sebagai gagasan filsafat sosial yang matang dari para pemimpin nasionalis Indonesia yang paling penting (Kahin, 1995). Soekarno sukses memadukan gagasan-gagasan besar secara jelas antara apa yang ditangkap oleh pikiran para pemimpin yang terpelajar dan ungkapan bahasa simbolik yang dirangkum dari pemikiran rakyat jelata yang tidak berpendidikan. Kahin sampai berkesimpulan bahwa inilah contoh sintesa demokrasi Barat, gagasan Islam modernis, Marxist, serta gagasan demokrasi dan komunalistis yang berasal dari desa yang membentuk ide dominan dalam Pancasila.

Berbeda dengan cara pandang Kahin, Yamin seorang tokoh ultranasionalis sekaligus tokoh utama pergerakan kemerdekaan Indonesia, menyebut Pancasila yang digagas Soekarno berasal dari ide murni bersifat lokal, digali dari identitas multikultural bangsa ini sebagaimana dalam buku Negarakertagama, yang ditulis Empu Prapanca, seorang penyair istana pada masa kerajaan Hindu Majapahit (1296-1478 M). Soekarno, menurut Yamin, hanya mengambil alih tema Pancasila Prapanca ini dan memberinya isi dan makna baru (Maarif, 1985). Dibandingkan pendekatan Kahin yang rasional-empiris, rumusan Pancasila melalui pendekatan Yamin tampaknya lebih dapat diterima, mengingat peminjaman istilah Pancasila oleh Soekarno yang terambil dari sumber lokal sarat nilai-nilai 
budaya, bahkan tampak suasana logosentris dari watak asli bangsa Indonesia ketika silasilanya dinarasikan.

Prinsip pertama yang diajukan Soekarno dalam rumusan Pancasila adalah nasionalisme, sebuah ide baru kebangsaan multikultur yang diikat oleh prinsipprinsip kesamaan perjuangan politik. Dalam pidatonya ia menyebut bahwa, "nasionalisme bukanlah sekadar satu golongan orang yang hidup dengan le desir d'etre ensemble' di atas daerah yang kecil seperti Minangkabau, atau Madura, atau Yogya, atau Sunda, atau Bugis, tetapi bangsa Indonesia adalah seluruh manusia yang menurut geopilitik telah ditentukan oleh Allah swt tinggal di kesatuannya semua pulau-pulau Indonesia dari ujung utara Sumatera sampai ke Irian!...kita hanya dua kali mengalami nationale-staat, yaitu di zaman Sriwijaya dan di zaman Majapahit” (Kahin, 1995). Soekarno nampak berhati-hati dalam menjelaskan konsep nasionalisme yang dalam tradisi politik Barat justru seringkali terjebak kedalam bentuk "chauvinisme". Ia tetap mendasarkan nasionalismenya dengan menggali nilai-nilai multikultural sebagai warisan peradaban Nusantara yang tumbuh secara organis, sehingga tak mungkin dibentuk atau diubah dengan memaksakan nilai-nilai kultur dari luar.

Nasionalisme menjadi pokok utama dalam pemikiran Soekarno tentang Pancasila, sekalipun kelima prinsip dasar yang diajukan tersebut diperas lagi menjadi hanya satu prinsip (ekasila) dengan istilah "gotong-royong", dimana nilai nasionalisme khas Indonesia masih tetap sangat kuat.
Kesadaran nasionalisme Indonesia yang mulai tumbuh sejak dasawarsa pertama abad ke-20 juga berpengaruh terhadap dirinya terutama jika membaca berbagai tulisannya di beberapa media lokal. Jejak nasionalisme-sekuler yang hidup dalam pemikirannya, tak jarang menuai polemik, terutama dengan para aktivis Muslim. Perdebatan Soekarno dengan Natsir, dengan mengusung tema sensitif politik menyoal hubungan negara-agama, hampir menjadi suatu konflik terbuka, yang mencapai puncaknya ketika Soekarno melancarkan kritik terhadap para ulama yang disebutnya sebagai "kaum yang tak tahu sejarah" (Natsir, 1973).

Ide nasionalisme Soekarno lewat pidatonya tentang Pancasila, menurut saya, merupakan pokok dari keseluruhan sila-sila berikutnya yang ia kembangkan. Konsep nasionalisme Soekarno memang unik, karena ia tidak mengakui definisi nasionalisme Barat pada umumnya yang masih dinilai sempit dan sektarian. Ia misalnya, menolak definisi Ernest Renan yang mendefinisikan nasionalisme sebagai "kehendak untuk bersatu" (le desire d'etre ensamble), sekaligus tak sependapat dengan Otto Baeur yang menyebut nasionalisme (natie) sebagai satu perangai yang timbul karena persatuan nasib. Soekarno melihat lebih jauh dengan memadukan unsur "manusia" sebagai penggerak perubahan dan "tempat" dimana manusia Indonesia hidup dalam kenyataan tradisi dan budaya yang berbeda-beda. "Kalau kita melihat peta dunia, kita dapat menunjukkan dimana 'kesatuan-kesatuan' disitu...Pada peta itu dapat ditunjukkan satu kesatuan gerombolan pulau-pulau", demikian Soekarno ketika menjelaskan prinsip- 
prinsip nasionalisme yang lebih khas dengan mengambil nilai-nilai multikultural yang telah berkerak dalam batin masyarakat Nusantara.

Setelah ide nasionalismemultikultur dengan mengambil dari sumber-sumber klasik realitas kebangsaan Indonesia yang disatukan secara politik, seperti "persatuan" dua kerajaan besar Nusantara, Soekarno memperluasnya dengan suatu konsep nasionalisme menuju persatuan dunia. Ia menawarkan prinsip internasionalisme dan prikemanusiaan, sebagaimana pidatonya yang dikutip Kahin: "Kita bukan saja harus mendirikan Negara Indonesia Merdeka, tetapi kita harus menuju pula pada kepada kekeluargaan bangsa-

bangsa...inilah filosofi prinsip nomor dua yang saya usulkan kepada tuan-tuan, yang boleh saya namakan internasionalisme" (Kahin,1995). Bagi Soekarno, nasionalisme dan internasionalisme merupakan dua prinsip yang tidak bisa dipisahkan, sebab bagaimanapun internasionalisme tidak dapat hidup dalam buminya nasionalisme. Sebuah bangsa yang besar adalah bangsa yang disegani dunia internasional dan ketika dikaitkan dengan prinsip prikemanusiaan, berarti ia dapat secara aktif terlibat dalam relasi-relasi kemanusiaan dalam skala global.

Dalam hal penolakannya terhadap bentuk negara Islam, Soekarno mengajukan prinsip ketiga dari Pancasila yang disebutnya sebagai perwakilan dan permusyawaratan. Tampak disini Soekarno ingin mengambil tema-tema politik Islam secara substantif dimana kedua istilah diatas (wakil dan musyawarah) merupakan tema besar dalam praktik politik Islam. Perwakilan berarti memberikan ruang kompetisi politik bagi kelompok manapun untuk berjuang bersama-sama dalam kontestasi agar terakomodasi dalam struktur-struktur politik. Disisi lain prinsip musyawarah memungkinkan setiap perbedaan kepentingan dalam sistem politik dikompromisasikan sehingga mencegah dominasi kelompok tertentu dalam struktur kekuasaan. Beberapa peristiwa yang mencitrakan dirinya bersikap konfrontatif dengan kalangan Islam, seperti menemukan momentumnya dalam pidatonya tentang Pancasila ini, dengan menyatakan, "Untuk pihak Islam, inilah tempat terbaik untuk memelihara agama...dengan cara mufakat, kita perbaiki segala hal; kepentingan agama kita tingkatkan...Badan Perwakilan inilah tempat kita untuk mengemukakan tuntutan-tuntutan Islam" (Kahin, 1995).Dalam tawaran prinsipnya yang keempat soal keadilan sosial dan kesejahteraan, Soekarno tampaknya telah sangat akrab dengan ideologi komunisme yang mengusung tema-tema keadilan dan persamaan rakyat-yang berimplikasi pada teori tentang perjuangan kelas-ditengah dominasi "kelas penguasa" kaum kapitalis. Bukan suatu kebetulan, dimana runtuhnya kolonialisme juga akibat tidak langsung dari penetrasi ideologi komunis ke seluruh dunia, terutama negara-negara yang belum merdeka sehingga pengaruh komunisme membangkitkan semangat nasionalisme dalam melawan kolonialisme. Nuansa Marxian akan terasa ketika ia menyebut dalam pidatonya, "Apakah kita mau Indonesia Merdeka yang kaum kapitalnya merajalela, ataukah yang semua rakyatnya 
sejahtera, yang semua orang cukup makan, cukup pakaian, hidup dalam kesejahteraan, merasa dipangku oleh Ibu Pertiwi yang cukup memberi sandang pangan kepadanya?"

Soekarno secara gamblang mengkritik demokrasi Barat yang sejauh ia pahami masih mempertahankan ciri-ciri kapitalistiknya dengan mengabaikan aspek pemerataan ekonomi dan sosial. Lalu, dalam pidatonya ia melanjutkan, “...Kalau kita mencari demokrasi, hendaknya bukan demokrasi Barat, tetapi...demokrasi ekonomi-politik yang mampu mendatangkan ke Terlepas dari berbagai perdebatan kritis terhadap wacana Pancasila ini, pada akhirnya Pancasila tetap diakui dan disepakati bersama sebagai sebuah ideologi negara sekaligus bentuk kompromi politik yang dapat menjembatani segala perbedaanperbedaan kultural. Pancasila, tidak hanya konsensus atas suatu falsafah dan ideologi negara, namun secara lebih jauh menjalankan suatu kerangka ideologis dalam proses integrasi sosial dan politik dalam masyarakat Indonesia. Pancasila mena-warkan aspek multukulturalisme secara organik, yang secara alami menjaga nilai-nilai pluralitas dan pada saat yang sama memberikan kesetaraan hak-hak politik kepada seluruh warga negara, tanpa menonjolkan simbolsimbol atau membiarkan dominasidominasi kebudayaan tertentu atas lainnya.

Indonesia memiliki serangkaian pengalaman yang sangat mengagumkan dalam konteks integrasi sosio-kultural, sekalipun dalam beberapa kasus, proses integrasi tersebut tetap menunjukkan realitas pasang-surut, sekalipun dalam banyak hal, tetap menunjukkan stabilitasnya sebagai suatu masyarakat multikultural yang sangat besar. Persoalan disintegrasi memang sempat terjadi beberapa tahun setelah Pancasila ditetapkan menjadi ideologi negara, seperti muncul serangkaian pergolakan yang serius dibeberapa daerah. Pada 1947, meletus pemberontakan Darul Islam di Jawa Barat, lalu tiga tahun berikutnya disusul oleh gerakan pemisahan diri di Maluku padaakhir April 1950. Pergolakan ini tetap berlanjut pada masa-masa berikutnya, sebagaimana muncul gerakan Organisasi Papua Merdeka (OPM) pada 1976 tepat setelah Belanda mengembalikan kedaulatan Irian Barat kepada Republik Indonesia.

Berbagai peristiwa tersebut tentusaja bagian integral dari proses pembentukan nasionalisme yang lebih matang, suatu proses integrasi atau multikulturalisme yang berjalan secara organik. Kelancaran dari suatu proses pembinaan kesetiaan nasional erat kaitannya dengan kematangan suatu budaya politik. Kematangan budaya politik suatu bangsa-menurut Ake-adalah suatu prakondisi yang penting bagi suatu integrasi yang tinggi tingkatnya, sehingga masalah-masalah terkait dengan pengarahan kesetiaan lokal kepada pemimpin nasional dan masalah peningkatan konsensus normatif dapat diatasi dengan lancar (Sjamsuddin, 1989).

Saya justru sepakat dengan model 
penguatan identitas nasional yang diajukan Parekh daripada istilah "multikulturalisme" yang dalam kasus Eropa justru lebih banyak dibentuk oleh "kultus" atas liberalisme yang lebih menguntungkan ide-ide kelompok minoritas seraya mengasingkan budaya lokalnya sendiri. Disisi lain, Kymlicka menawarkan istilah "multikulturalisme liberal demokratis" yang lebih mendorong kepada pengakuan semua hak sipil, baik budaya, agama, ras, atau etnisitas yang mendapat perlindungan dan jaminan hak yang sama dalam struktur-struktur sosial- politik secara legal. Namun, Pancasila sejauh ini telah lebih dulu memberikan jaminan atas hak-hak politik warga negara dalam kerangka multikulturalisme organik, yang mengakui pluralitas, menjaga dan merawat warisan-warisan budaya dan nilai- nilai moral masyarakat, tanpa harus menempatkan satu budaya dominan sehingga menjadikan budaya lainnya menjadi subdominan.

Indonesia memiliki serangkaian pengalaman integrasi multikulturalisme yang istimewa

(priveleged multiculturalism) yang seharusnya dapat menjadi model bagi negara-negara Barat yang "gagal" menerapkan model strategi liberal demokratik multikulturalisme. Negaranegara Barat-seperti Eropa dan Amerika-tidak pernah melihat bagaimana negara-negara Asia, khususnya Indonesia-tetap mempertahankan cara-cara

tradisional dalam proses integrasinya. Meskipun belakangan ini, muncul upayaupaya tertentu untuk menjalankan itegrasi sosial dan politik melalui model multikulturalisme liberal, melalui pengenalan simbol-simbol asing yang mengangkat hak-hak minoritas kelompok tertentu. Munculnya kelompok LGBT yang menuntut pengakuan haknya sebagai komunitas sosial dalam legalitas negara merupakan salah satu kasus dimana model multikulturalisme liberal mengganggu proses multikulturalisme organik yang sejauh ini berjalan di Indonesia.

Saya kira, perlu revitalisasi prinsip-prinsip dasar kebangsaan dan kenegaraan melalui upaya perkenalan pendidikan multikultur. Hal ini penting, mengingat perjalanan multikulturalisme di Indonesia yang dibingkai melalui ideologi Pancasila dan konsep bhineka tunggal Ika, hampir- hampir mengalami pengeroposan integrasi. Kita pernah mengalami pengalaman tidak menyenangkan, ketika Pancasila sekadar menjadi alat politik kekuasaan di era Orde Baru. Lalu, pada masa pemerintahan BJ Habibie dalam ingterregnumnya tidak hanya menerapkan demokrasi multi-partai, melainkan juga menghapus kewajiban asas tunggal Pancasila. Ide rejuvenasi Pancasila yang dicanangkan oleh Azyumardi Azra, memang cukup mendesak terutama ketika kita merasakan bahwa Pancasila semakin termarjinalkan (Suparto, 2010).

\section{Kesimpulan}

Kemampuan Indonesia dalam menerapkan model multikulturalisme organik, memiliki keterikatan sejarah 
yang sangat dekat dengan proses islamisasi di masa lalu, dimana nilai-nilai ajaran Islam yang terbuka dan moderat, membuka jalan yang lebih luas terhadap suatu proses integrasi budaya, sosial, politik dalam masyarakatnya yang multietnik. Islam dalam banyak hal, memiliki kesesuaian dan keselarasan dengan tradisi dan budaya masyarakat lokal, sehingga, sekalipun Islam menjadi agama mayoritas di Indonesia, namun tidak menuntut adanya homogenitas kultur atau penonjolan simbol-simbol keagamaannya secara dominan. Sekalipunintegrasi sosial dan politik ini masih merupakan proses yang terus berjalan menuju suatu kematangan budaya politik masyarakatnya, Indonesia tetap mempertahankan cara-cara tradisionalnya dengan tidak mengimpor model Barat yang bermasalah dalam proses integrasi sosialnya.

Islam menjadi agama penting dalam membentuk Indonesia yang khas, mampu memadukan secara harmonis aspek-aspek kulturalnya, berjalan beriring tanpa harus berbenturan antara apa yang dimaksud dengan wilayah agama yang sakral dan aspek sosial kemasyarakatan yang bernilai profan. Barangkali, sulit menemukan pengalaman dalam bentuk kekhasan multikulturalisme (priveleged multikulturalism) seperti di Indonesia dan Malaysia misalnya, sebab negara-negara Asia Tenggara lainnya dalam proses integrasinya tidak memiliki kekhasan seperti mereka, kecuali kemampuannya secara alami dalam hal egalitarianmultikulturalisme, karena nilai-nilai sosial yang terbuka sebagai ciri khas budaya Asia.

Islam, Multikulturalisme, dan Pancasila, seolah menjadi tiga serangkai yang terus hidup memberikan warna bagi Indonesia dalam proses mempertahankan nilai-nilai tradisionalismenya, menjaga dan merawat kenyataan multikultural masyarakatnya, memberikan kesempatan politik secara sama kepada siapapun tanpa memandang latar belakang suku, agama, atau kelompok tertentu. Pancasila dalam banyak hal, mampu menjadi titik temu semua, keragaman agama, budaya, dan etnis, dan memadukannya dalam keragaman sosial tanpa harus menonjolkan salah satu unsur dan menekan rendah unsur lainnya. Merawat multikulturalisme organik secara alami dan tradisional dengan menolak model multikulturalisme liberal jelas adalah tujuan Pancasila yang lebih menekankan aspek identitas nasional dari pada mengikuti identitas asing yang ternyata bermasalah.sejahteraan sosial! Rakyat Indonesia sudah lama bicara tentang hal ini. Apakah yang dimaksud Ratu Adil? Ini adalah keadilan sosial”. Konsep keadilan sosial yang dimaksud oleh Soekarno ini barangkali wujud dari suatu pemerataan politik-ekonomi yang tidak hanya dinikmati segelintir pemimpinnya yang terakomodasi dalam badan-badan perwakilan, tetapi juga harus peduli dan memikirkan nasib rakyatnya yang jauh lebih besar jumlahnya.

Pada bagian terakhir dari lima prinsip yang ia tawarkan, ide negara berketuhanan bagi Indonesia justru baru muncul ke permukaan. Menariknya, Tuhan dalam gambaran ide Soekarno tidak sama 
sekali "tunggal" tetapi "banyak", sebagaimana yang dikutip dari pidatonya yang ditulis oleh Kahin, "Bukan saja bangsa Indonesia berTuhan, tetapi masing-masing orang Indonesia hendaknya berTuhan, Tuhannya sendiri. Yang Kristen menyembah Tuhan menurut petunjuk Isa Al Masih; yang Muslim menurut petunjuk Nabi Muhammad; orang Buddha menjalankan ibadatnya menurut kitabkitab yang ada padanya". Sekalipun dalam kesimpulan pidatonya, konsep Ketuhanan ini seperti dianulir menjadi Kepercayaan kepada Tuhan Yang Maha Esa, namun konsep ini belakangan tetap menuai polemik, terutama antara golongan Islam dan kelompok nasionalis.

Melihat kepada lima prinsip dasar bernegara yang diinisiasi Soekarno yang meliputi nasionalisme, internasionalisme atau prikemanusiaan, perwakilan atau permusyawaratan, keadilan sosial dan kesejahteraan, serta Ketuhanan, merupakan intisari dari filsafat sosial. Manusia menempati kedudukan sentral sebagai agen perubahan sosial yang terus berproses untuk "menjadi". Maka, Pancasila sebagai sebuah konsep kerja tak jarang menjadi ajang perdebatan sengit dalam sidangsidang majelis, terutama antara kelompok yang dikategorikan nasionalis-sekuler dan agama. Kahin dan Feith menyebut Pancasila sebagai suatu falsafah sosial, dimana didalamnya terdapat nilai-nilai

kemanusiaan yang di gali dari warisan budaya masyarakat Indonesia. disisi lain, Sutan Takdir Alisjahbana dan Saifuddin Zuhri-keduanya tokoh

Muslim- melihatnya sebagai paham multikultural yang seluruh silanya masih kontradiktif, belum dapat disebut sebagai suatu kesatuan paham bersama (Maarif, 1985).

\section{Daftar Pustaka}

Goldziher, I. (1991). Pengantar Teologi dan Hukum Islam. Jakarta: INIS.

Grunebaum, G. E. (1983). Islam Kesatuan dalam Keragaman. Jakarta: Yayasan Obor Indonesia.

Hidayat, K. (2004). Menafsirkan Kehendak Tuhan. Jakarta: Teraju.

Hodgson, M. G. (1999). The Venture of Islam: Iman dan Sejarah dalam Peradaban Dunia. Jakarta: Paramadina.

Kahin, G. (1995). Nasionalisme dan Revolusi di Indonesia. Solo: UNS Press.

Lewis, B. (1994). Bahasa Politik Islam. Jakarta: Gramedia.

Maarif, A. S. (1985). Islam dan Masalah Kenegaraan. Jakarta: LP3ES.

Martin, R. C. (1982). Islam a Cultural Perspective. London: Prentice Hall.

Munoz, G. M. (1999). Islam Modernism and The West. London: I.B. Tauris.

Nagy, S. R. (2013). Politics of Multiculturalism in East Asia: Reinterpreting Multiculturalism. Ethnicities, Vol 14 No 1, 160.

Natsir, M. (1973). Capita Selecta. Jakarta: UB Ideal.

Rahman, F. (2017). Tema-tema Pokok AlQur'a. Bandung: Mizan.

Rasmussen, A. K. (2010). Women, The Recited Qur'an, and Islamic Music in Indonesia. California: University of California Press.

Sjamsuddin, N. (1989). Integrasi Politik di Indonesia. Jakarta: Gramedia. 
Suparto, R. A. (2010). Cerita Sukses Pendidikan Multikultural di Indonesia. Jakarta: CSRC UIN Jakarta.

Waardenburg, D. J. (1993). "Islam Dikaji Sebagai Sistem Simbol dan Signifikasi" dalam Studi Belanda Kontemporer Tentang Islam. Jakarta: INIS.

Watt, W. M. (1982). Muhammad Nabi dan

Negarawan. Jakarta: CV Kuning Mas.

Wordpower, O. (2011). Kamus Oxford

Wordpower. New York: Oxford

University Press.

www.almaany.com. (n.d.). 